\title{
SUPERVISI PENDIDIKAN PADA SEKOLAH DASAR
}

\author{
JULFANDRIANSYAH
}

Email : fandi7798@gmail.com

\begin{abstract}
ABSTRAK
Supervisi pendidikan adalah segala usaha pejabat sekolah dalam memimpinguru-guru dan tenaga kependidikan lainnya, untuk memperbaiki pengajaran termasuk menstimulasi, menyeleksi pertumbuhan dan perkembangan jabatan guru-guru, menyeleksi dan merevisi tujuan-tujuan pendidikan, bahan pengajaran, dan metode-metode mengajarserta evaluasi pengajaran.Beberapa instrumen yang terkait dengan supervisi pendidikan sekolah dasar yaitu: (1) instrumen monitoring penerimaan dan orientasi siswa baru, (2) instrumen pengendali jadwal pelajaran, (3) instrumen pemantauan pelaksanaan ulanganumum bersama, (4) instrumen pemantauan pelaksanaan Ujian Nasional (UN) (5) instrumensupervisi administrasi sekolah, (6) instrumen supervisi administrasi kelas, dan (7) instrumen observasi kelas.
\end{abstract}

Kata kunci : supervisi pendidikan, peningkatan kualitas, guru, instrumen.

\section{LATAR BELAKANG}

kepala sekolah mempunyai peran sebagai supervisor. Kepala sekolah sebagai supervisor amat berperan dalam menentukan pelaksanaan supervisi di sekolah. Supervisi adalah suatu proses pembimbingan dari pihak atasan kepada guru-guru dan para personel sekolah lainnya yang langsung menangani belajar para siswa, untuk memperbaiki situasi belajar mengajar agar parasiswa dapat belajar secara efektif sehingga prestasi belajar semakin meningkat (Pidarta, 1992). Melalui supervisi, diharapkan seorang guru dapat: (1) bekerja keras dan demokratis, (2) ramah dansuka mendengarkan orang lain, (3) sabar, (4) luas pandangan dan menaruh perhatian kepada orang lain, (5) penampilan pribadi yang menyenangkan dan sopan santun, (6) jujur, (7) suka humor, (8) kemampuan kerja yang baik dan konsisten, (9) menaruh perhatian pada problem siswa, (10) fleksibel dalam cara mengajar, (11) bisa menggunakan pujian dan mau memperbaiki, (12) pandai dalammengajar pada bidang studi Oleh karena itu supervisi dalam pendidikan sangat besar pengaruhnya terhadap peningkatan kinerja guru yang pada gilirannya dapat meningkatkan mutu pendidikan.

\section{PEMBAHASAN}

supervisi bertujuan mengembangkan iklim yang kondusif dan lebih baik dalam kegiatan belajar- mengajar, melalui pembinaan dan peningkatan profesi mengajar. Dengan kata lain tujuan supervisi pengajaran adalah membantu dan memberikan kemudahan kepada para guru untuk belajar bagaimana meningkatkan kemampuan mereka guna mewujudkan tujuan belajar peserta didik. Secara khusus, Amatembun (dalam Mulyasa, 2002) mengemukakan bahwa tujuan supervisiadalah untuk: (1) membina kepala sekolah dan guruguru untuk lebih memahami tujuan pendidikan yang sebenarnya dan peranan sekolah dalam 
merealisasikan tujuan tersebut, (2) memperbesar kesanggupan kepala sekolah dan guru-guru untuk mempersiapkan peserta didiknya menjadi anggota masyarakat yang lebih efektif, (3) membantu kepala sekolah dan guru mengadakan diagnosis secara kritis terhadap aktivitasaktivitasnya dan kesulitan-kesulitan belajar mengajar, serta menolong mereka merencanakan perbaikan, (4) meningkatkan kesadaran kepala sekolah dan guru-guru serta warga sekolah lain terhadap cara kerja yang demokratis dan komprehensif, serta memperbesar kesediaan untuk tolong- menolong,(5) memperbesar semangat guru-guru meningkatkan motivasi berprestasi untuk mengoptimalkan kinerja secara maksimal dalam profesinya,(6) membantu kepala sekolah untuk mempopulerkan pengembangan program pendidikan di sekolahkepada masyarakat, (7) melindungi orang-orang yang disupervisi terhadap tuntutan- tuntutanyang tidak wajar dan kritik-kritik yang tidak sehat dari masyarakat,(8) membantu kepala sekolahdan guru-guru dalam mengevaluasi aktivitasnya untuk mengembangkan aktivitas dan kreativitaspeserta didik,(9) mengembangkan rasa kesatuan dan persatuan di antara guru-guru.

Sedangkan yang dikemukaan Sabandi (sabandi, 2013), pelaksanaan supervisi dilakukan bertujuan untuk menjamin pembelajaran yang berkualitas di suatu sekolah. Keberhasilan pelaksanaan supervisi juga berpengaruh terhadap peningkatan prestasi belajar siswa. Artinya, semakin baik pelaksanaan supervisi, semakin tinggi kinerja guru, maka semakin tinggi pula prestasi belajar yang dicapai siswa. Oleh karena itu, agar kinerja guru semakin tinggi maka diperlukan pelaksanaan supervisi yang efektif.

\section{PENUTUP}

\section{Kesimpulan}

Pada lembaga pendidikan sekolah dasar yang menjadi supervisor adalah kepala sekolah. Kepala sekolah mengarahkan dan membimbing guru dalam sekolah atau mensupervisi guru. Supervisi merupakan bantuan yang diberikan kepada seluruh staf dan guru untuk mengembangkan situasi belajar-mengajar yang baik. Tujuan supervisi ialah membantu memperbaiki dan meningkatkan pengelolaan sekolah sehingga tercapai kondisi belajar mengajar yang baik

\section{Saran}

Berdasarkan tujuan supervisi tersebut diharapkan guru dapat bekerja keras, demokratis, ramah, sabar, luas pandangan, sopan-santun, jujur, suka humor, konsisten, fleksibel, dan lain-lain. Agar supervisi mendapatkan hasil yang baik, hendaknya supervisor bersikap bersahabat, mendengarkan pembicaraan,berusaha meningkatkan partisipasi, ikut menyumbang teknik menganalisis permasalahan, memberi saran-saran, mencatat rencana, membuat ringkasan dan membuat penilaian.

\section{REFERENSI}

Sabandi, A. (2013). Supervisi Pendidikan Untuk Pengembangan Profesionalitas Guru Bekelanjutan. Pedagogi,jurnal ilmiah ilmu pedidikan, XIII(2), 1-9. Retrieved From Http://Ejournal.Unp.Ac.Id/Index.Phd/Pedagogik/Articele/View/4275 
Pidarta, Made.(1992).Pemikiran Tentang Supervisi Pendidikan. Jakarta: Bumi Aksara.

Mulyasa.(2002).Manajemen Berbasis Sekolah. Bandung: Remaja Rosdakarya. 